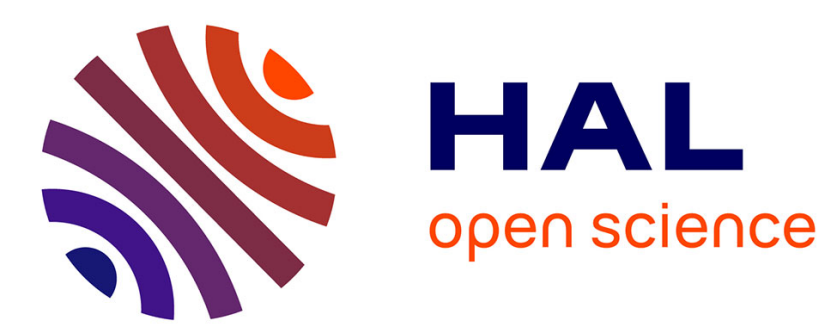

\title{
A new analytical protocol for the determination of 62 endocrine-disrupting compounds in indoor air
}

Stéphanie Laborie, Elodie Moreau-Guigon, Fabrice Alliot, Annie Desportes, Lucie Oziol, Marc Chevreuil

\section{- To cite this version:}

Stéphanie Laborie, Elodie Moreau-Guigon, Fabrice Alliot, Annie Desportes, Lucie Oziol, et al.. A new analytical protocol for the determination of 62 endocrine-disrupting compounds in indoor air. Talanta, 2016, 147, pp.132-141. 10.1016/j.talanta.2015.09.028 . hal-01211426

\section{HAL Id: hal-01211426 https://hal.sorbonne-universite.fr/hal-01211426}

Submitted on 5 Oct 2015

HAL is a multi-disciplinary open access archive for the deposit and dissemination of scientific research documents, whether they are published or not. The documents may come from teaching and research institutions in France or abroad, or from public or private research centers.
L'archive ouverte pluridisciplinaire HAL, est destinée au dépôt et à la diffusion de documents scientifiques de niveau recherche, publiés ou non, émanant des établissements d'enseignement et de recherche français ou étrangers, des laboratoires publics ou privés. 


\title{
A new analytical protocol for the determination of 62 endocrine-disrupting compounds in indoor air
}

\author{
Stéphanie Laborie $*^{\mathrm{a}}$, Elodie Moreau-Guigon ${ }^{\mathrm{a}}$, Fabrice Alliot ${ }^{\mathrm{a}}$, Annie Desportes ${ }^{\mathrm{a}}$, \\ Lucie Oziol $^{\mathrm{b}}$, Marc Chevreuil ${ }^{\mathrm{a}}$ \\ a. Sorbonne Universités, UPMC Univ Paris 06, CNRS, EPHE, UMR 7619 Metis, 4 place Jussieu, 75005 Paris, \\ France \\ b. Université Paris Sud, CNRS, AgroParisTech, UMR 8079, ESE, F-91405, Orsay, France \\ * $\underline{\text { stephanie.laborie@upmc.fr }}$; UPMC - 4, place jussieu - UMR 7619 METIS - case 105 - 75005 Paris ; \\ phone: +33144275134
}

ABSTRACT: The objective of this study was to develop and validate a new analytical protocol for simultaneous determination of 62 semi-volatile organic compounds in both phases of indoor air. Studied compounds belong to several families: polybrominated diphenyl ethers, polychlorinated biphenyls, hexachlorobenzene, pentachlorobenzene, phthalates, polyaromatic hydrocarbons, parabens, tetrabromobisphenol A, bisphenol A, hexabromocyclododecane, triclosan, alkylphenols, alkylphenol ethoxylates, synthetic musks (galaxolide and tonalide) and pesticides (lindane and cypermethrin). A medium volume sampling system was used to collect

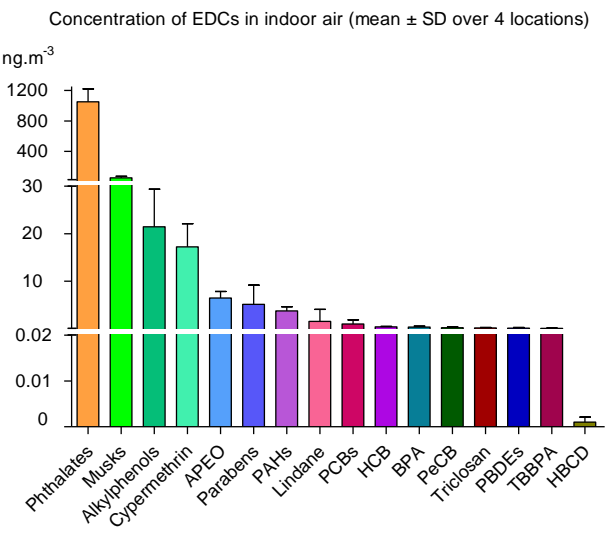
simultaneously these endocrine-disrupting compounds (EDCs) from the gaseous and particulate phases. An accelerated solvent extraction method was optimized to obtain all EDCs in a single extract by atmospheric phase. Their extraction from the sorbents and their analysis by liquid and gas chromatography-mass spectrometry (LC/MS/MS, GC/MS and GC/MS/MS) was validated using spiked sorbents (recovery study and analytical uncertainty analysis by fully nested design). The developed protocol achieved low limits of quantification $\left(<0.5 \mathrm{ng} \cdot \mathrm{m}^{-3}\right)$ and low uncertainty values $\left(<5 \mathrm{ng} \cdot \mathrm{m}^{-3}\right)$ for all compounds. Once validated, the method was applied to indoor air samples from four locations (a house, an apartment, a day nursery and an office) and compared to literature to confirm its efficiency. All target EDCs were quantified in the samples and were primarily present in the gaseous phase. The major contaminants found in indoor air were, in descending order, phthalates, synthetic musks, alkylphenols and parabens.

Keywords: endocrine disruptors, indoor air, liquid chromatography, gas chromatography, mass spectrometry.

\section{1- INTRODUCTION}

Over the last decade, evidence has accumulated concerning the potential adverse effects of exposure to environmental chemicals that interact with the endocrine system [1-3]. Humans are chronically exposed to many compounds at low levels in water [4,5], air [6,7], and food $[8,9]$. Furthermore, adults and children spend much of their time indoors, where the air is often more contaminated than outdoors $[10,11]$. Various factors can explain the increasing accumulation of contaminants in indoor environments, such as the rapid development of new building materials, furnishings and consumer products and lower air exchange rates for improved energy efficiency [12]. Moreover, air inhalation represents a chronic and passive exposure route for environmental 
pollutants. Therefore, characterization of indoor air contamination remains an important public health issue.

Many indoor contaminants have been identified [12,13]. Some are endocrine-disrupting compounds (EDCs), which may cause endocrine disorders in animals and humans [14]. Many known or suspected EDCs can be found in the indoor air environment due to their semi-volatility, including flame retardants $[15,16]$, surfactants $[17,18]$, plasticizers $[19,20]$, bactericides $[21,22]$, or synthetic musks [23,24]. Given the health hazard of EDCs and their possible environmental persistence at low doses, it is essential to precisely characterize human exposure to these contaminants.

Several analytical protocols have been developed for the quantification of semi-volatile organic compounds (SVOCs) in indoor air (Table 1). Most of them include an extraction step mainly based on Sohxlet method that may be solvent or time-consuming, or pretreatment steps that increase the sample preparation time (clean-up step) or need high sample amounts (derivatization step). The great majority of these studies were applied to one or two families of EDCs having similar polarities. The only ones that have analyzed a larger number of EDCs employed pretreatment steps or collected sample volumes too small to allow quantification of EDCs at low indoor concentrations (i.e polybrominated diphenyl ethers (PBDEs) or polychlorinated biphenyls (PCBs)). To date, there are no published multi-residue methods for quantification of low levels of EDCs in indoor air, from gaseous and particulate extracts prepared simultaneously in single-step.

Thus, the primary objective of this study was to develop and validate an analytical method to quantify sixty-nine SVOCs in indoor gaseous and particulate phases from a single extract. The analytical process was optimized in reference to the existing protocols (Table 1), in order to use lower solvent volumes, lower sample amounts and shorter extraction times, improving thus the sample throughput. The target compounds belong to several families of EDCs displaying different physicochemical properties: PBDEs, PCBs, hexachlorobenzene (HCB), pentachlorobenzene (PeCB), phthalates, polyaromatic hydrocarbons (PAHs), parabens, tetrabromobisphenol A (TBBPA), bisphenol A (BPA), hexabromocyclododecane (HBCD), triclosan, alkylphenols (APs), alkylphenol ethoxylates (APEOs), synthetic musks (galaxolide and tonalide) and pesticides (lindane and cypermethrin). The high sampling volume allows detection and quantification of low levels contaminants and for the first time, triclosan in indoor air. PBDEs, PCBs, HCB, PeCB and lindane were analyzed by gas chromatography coupled with tandem mass spectrometry (GC/MS/MS); phthalates, synthetic musks, cypermethrin and PAHs were determined by gas chromatography coupled with single mass spectrometry (GC/MS); and parabens, TBBPA, BPA, TCS, HBCD, APs and APEOs were quantified by liquid chromatography coupled with tandem mass spectrometry (LC/MS/MS). The developed analytical protocol was applied to a set of air samples collected from four indoor environments. 
Table 1. Selected analytical protocols for EDCs analysis in indoor air.

\begin{tabular}{|c|c|c|c|c|c|c|c|}
\hline $\begin{array}{l}\text { Compou } \\
\text { nds studied }\end{array}$ & $\begin{array}{c}\text { Atmospheric phase } \\
\text { studied }\end{array}$ & $\begin{array}{l}\text { Sampling } \\
\text { method }\end{array}$ & $\begin{array}{c}\text { Active } \\
\text { sampling } \\
\text { volume }\left(\mathrm{m}^{3}\right)\end{array}$ & $\begin{array}{l}\text { Extraction } \\
\text { method }\end{array}$ & $\begin{array}{c}\text { Pretreatment } \\
\text { step }\end{array}$ & $\begin{array}{l}\text { Analysis } \\
\text { method }\end{array}$ & ${ }_{\text {ef. }} \mathrm{R}$ \\
\hline $\begin{array}{l}\text { HBCD } \\
\text { TBBPA }\end{array}$ & $\begin{array}{c}\text { Gaseous and } \\
\text { particulate separately } \\
\text { Results in gas + } \\
\text { particle }\end{array}$ & $\begin{array}{l}\text { PUF + filter } \\
\text { (passive and active } \\
\text { sampling) }\end{array}$ & 56 & $\begin{array}{l}\text { Soxhlet (hex/CH2Cl2, 1/9 } \\
\text { v/v) }\end{array}$ & SPE (silica) & $\begin{array}{l}\text { LC/MS/MS (reverse } \\
\text { phase) }\end{array}$ & 6 \\
\hline $\begin{array}{r}104 \\
\text { EDCs } \\
(63 \\
\text { detected })\end{array}$ & gaseous + particulate & $\begin{array}{l}\text { XAD-2 + PUF + } \\
\text { filter } \\
\text { (active sampling) }\end{array}$ & 12 & $\begin{array}{l}\text { Soxhlet (hex+6\% diethyl } \\
\text { ether) } \\
\text { Shaking (DCM) }\end{array}$ & $\begin{array}{l}\text { Drying with sodium } \\
\text { sulfate } \\
\text { Derivatization }\end{array}$ & GC/MS &, $40^{35}$ \\
\hline $\begin{array}{c}57 \text { EDCs } \\
(34 \\
\text { detected) }\end{array}$ & $\begin{array}{c}\text { Gaseous and } \\
\text { particulate separately }\end{array}$ & $\begin{array}{c}\text { PUF + filter } \\
\text { (active sampling) }\end{array}$ & 20 & PLE (DCM) & Derivatization & $\begin{array}{c}\text { GC/MS/MS } \\
\text { GC/MS }\end{array}$ & 36 \\
\hline $\begin{array}{l}\text { PCB } \\
\text { PBDE }\end{array}$ & Gaseous & $\begin{array}{c}\text { PUF } \\
\text { (passive sampling) }\end{array}$ & - & Soxhlet (hex) & $\begin{array}{l}\text { Sulfuric acid + SPE } \\
\text { (florisil) }\end{array}$ & GC/MS & 47 \\
\hline 56 EDCs & $\begin{array}{l}\text { Gaseous and } \\
\text { particulate separately }\end{array}$ & $\begin{array}{l}\text { XAD-2 + filter } \\
\text { (active sampling) }\end{array}$ & 136 & Depression system (DCM) & $\begin{array}{l}\text { SPE (florisil, } \\
\text { silica/alumina, acidic } \\
\text { silica/silica/alumina) }\end{array}$ & $\begin{array}{c}\mathrm{GC} / \mathrm{MS} \\
\mathrm{GC} / \mathrm{MS} / \mathrm{MS} \\
\mathrm{LC} / \mathrm{MS} / \mathrm{MS} \text { (reverse } \\
\text { phase) }\end{array}$ & 26 \\
\hline $\begin{array}{l}\text { Phtalates } \\
\text { Musks } \\
(10 \\
\text { detected }) \\
\end{array}$ & Gaseous & $\begin{array}{c}\text { PUF } \\
\text { (active sampling) }\end{array}$ & 2 & $\begin{array}{l}\text { PLE (hex/diethyl ether 95/5 } \\
\text { v/v) }\end{array}$ & - & GC/MS & 37 \\
\hline Musks & Gaseous & $\begin{array}{c}\text { Tenax TA } \\
\text { (active sampling) }\end{array}$ & 5 & - & - & GC/MS & 38 \\
\hline $\begin{array}{l}\text { Alkylphe } \\
\text { nols }\end{array}$ & Particulate & $\begin{array}{c}\text { Solid phase } \\
\text { extraction disk + filter } \\
\text { (active sampling) }\end{array}$ & 14.4 & Ultrasonication (acetone) & Derivatization & GC/MS & 41 \\
\hline $\begin{array}{l}\text { PBDE } \\
\text { TBBPA }\end{array}$ & $\begin{array}{c}\text { Gaseous and } \\
\text { particulate separately }\end{array}$ & $\begin{array}{c}\text { PUF + filter } \\
\text { (active sampling) }\end{array}$ & 150 & Soxhlet (hex/DCM) & - & GC/MS & 42 \\
\hline $\mathrm{PAH}$ & $\begin{array}{c}\text { Gaseous and } \\
\text { particulate separately } \\
\text { Results in gas + } \\
\text { particle }\end{array}$ & $\begin{array}{c}\text { PUF + filter } \\
\text { (active sampling) }\end{array}$ & 29 & $\begin{array}{l}\text { Static extraction (hex/DCM } \\
4 / 1 \mathrm{v} / \mathrm{v} \text { ) }\end{array}$ & SPE (acidic silica) & GC/MS & 43 \\
\hline
\end{tabular}




\begin{tabular}{|c|c|c|c|c|c|c|c|}
\hline $\begin{array}{l}\text { Compou } \\
\text { nds studied }\end{array}$ & $\begin{array}{c}\text { Atmospheric phase } \\
\text { studied }\end{array}$ & $\begin{array}{l}\text { Sampling } \\
\text { method }\end{array}$ & $\begin{array}{r}\text { Active } \\
\text { sampling } \\
\text { volume }\left(\mathrm{m}^{3}\right)\end{array}$ & $\begin{array}{l}\text { Extraction } \\
\text { method }\end{array}$ & $\begin{array}{l}\text { Pretreatment } \\
\text { step }\end{array}$ & $\begin{array}{l}\text { Analysis } \\
\text { method }\end{array}$ & ef. ${ }^{R}$ \\
\hline $\mathrm{PAH}$ & $\begin{array}{l}\text { Gaseous and } \\
\text { particulate separately }\end{array}$ & $\begin{array}{c}\text { XAD-2 + filter } \\
\text { (active sampling) }\end{array}$ & 28.8 & $\begin{array}{l}\text { Soxhlet (hex/DCM 50/50 } \\
\text { v/v) } \\
\text { Sonication (hex/DCM 50/50 } \\
\text { v/v) }\end{array}$ & - & $\begin{array}{l}\text { HPLC/FLUO (reverse } \\
\text { phase) }\end{array}$ & 44 \\
\hline $\begin{array}{c}\text { PAH } \\
\text { PCB } \\
\text { PBDE } \\
\text { Pesticide } \\
\mathrm{s}\end{array}$ & Gaseous & $\begin{array}{c}\text { PUF } \\
\text { (passive sampling) }\end{array}$ & - & Soxhlet (DCM) & - & $\begin{array}{l}\text { HPLC/FLUO (reverse } \\
\text { phase) } \\
\text { GC/MS }\end{array}$ &, $46^{45}$ \\
\hline $\begin{array}{l}\text { PBDE } \\
\text { PCB }\end{array}$ & $\begin{array}{c}\text { Gaseous and } \\
\text { particulate separately } \\
\text { Results in gas + } \\
\text { particle }\end{array}$ & $\begin{array}{l}\text { PUF + filter } \\
\text { (passive and active } \\
\text { sampling) }\end{array}$ & 2.7 & Soxhlet (DCM) & $\begin{array}{c}\text { Sulfuric acid } \\
\text { SPE (sodium } \\
\text { sulfate/aluminium oxide) }\end{array}$ & GC/MS & 48 \\
\hline PBDE & $\begin{array}{c}\text { Gaseous and } \\
\text { particulate separately } \\
\text { Results in gas + } \\
\text { particle }\end{array}$ & $\begin{array}{c}\text { PUF + filter } \\
\text { (active sampling) }\end{array}$ & 9.1 & $\begin{array}{l}\text { PLE (petroleum ether or } \\
\text { DCM) }\end{array}$ & Filtration & GC/MS & 49 \\
\hline $\begin{array}{r}69 \text { EDCs } \\
(57 \\
\text { detected })\end{array}$ & $\begin{array}{l}\text { Gaseous and } \\
\text { particulate separately }\end{array}$ & $\begin{array}{c}\text { XAD-2 + filter } \\
\text { (active sampling) }\end{array}$ & 200 & PLE (DCM/MeOH, 2/1 v/v) & - & $\begin{array}{c}\text { GC/MS } \\
\text { GC/MS/MS } \\
\text { LC/MS/MS (reverse } \\
\text { phase) }\end{array}$ & $\begin{array}{l}\quad P r \\
\text { esent } \\
\text { study }\end{array}$ \\
\hline
\end{tabular}




\section{2- EXPERIMENTAL SECTION}

2.1- Standards and reagents. Quartz fiber filters (QMA; diameter $47 \mathrm{~mm}$; porous $0.3 \mu \mathrm{m}$ ) were supplied by Whatman (Fisher Scientific, Illkirch, France). Amberlite XAD-2 resin (particle size 20-60 mesh) was purchased from Supelco (Sigma-Aldrich, St. Quentin Fallavier, France).

Organic solvents of chromatographic quality (Merck Suprasolv) were obtained from VWR, Strasbourg, France). Helium and nitrogen (gas purity $99.999 \%$ ) were supplied by Air Liquid (Paris, France).

Mixed native PBDE standard solutions were purchased from Cambridge Isotope Laboratories (LGC Standards, Molsheim, France). Isotope-labeled PBDE compounds used as surrogate standards, were obtained from Wellington Laboratories (BCP Instruments, Irigny, France). PCB congeners were supplied by LGC Standards. HCB and PeCB were purchased from Dr. Ehrenstorfer Reference Materials (CIL Cluzeau, Sainte-Foy-la-Grande, France) and LGC Standards, respectively. Phthalates (native and isotope-labeled standards) were purchased from Supelco. PAHs (native and isotope labeled standards) and the lindane-d6 standard were obtained from CIL Cluzeau. Parabens (native and isotope labeled standards) were purchased from Supelco. TBBPA and tetrabromo $\left({ }^{13} \mathrm{C}_{12}\right)$ bisphenol A (MTBBPA) were supplied by BCP instruments. BPA and BPA-d16 were purchased from A2S Analytical Standard Solution (CIL Cluzeau). Triclosan and HBCD (native and labeled standards) were obtained from Wellington Laboratories. APs and APEOs were purchased from Sigma Aldrich. Galaxolide, tonalide, cypermethrin, $\left({ }^{13} \mathrm{C}_{6}\right)$ cis-permethrin and lindane were supplied by Cambridge Isotope Laboratories (CIL Cluzeau and LGC Standards).

2.2- Sample collection. The sampling method was modified from a previous study[25]. Briefly, a 15-days integrated sampling was performed in the summer of 2013 at four sites near Paris, France: a house, an apartment, an office and a day nursery. This long period of sampling with a medium flow was chosen to ensure quantification of EDCs present at very low concentrations in indoor air (e.g $\mathrm{PCBs}$ or PBDEs). At each location, three consecutive samplings were performed. The particulate phase of the air was collected onto a QMA filter previously cleaned by heating at $400{ }^{\circ} \mathrm{C}$ for $4 \mathrm{~h}$. The filters were placed on open aluminum filter holders (Ecomesure, Janvry, France) and used in Total Suspended Particles (all particles that are suspended in air) sampling mode. The gaseous phase was collected onto Amberlite XAD-2 resin, which was previously cleaned using an extraction sequence with an accelerated solvent extraction (ASE 350 Dionex, Thermo Scientific). Three successive cleanup extractions were performed with methanol, acetone and hexane/dichloromethane $(50 / 50 \mathrm{v} / \mathrm{v})$. The XAD-2 resin was then dried under vacuum and placed in two brass cartridges (13 g on average distributed between the two cartridges): $A 1$ and A2 (13 mm diameter; $10 \mathrm{~cm}$ length). This sampling system (filter and resin cartridges) was connected to a sampling pump (Hailea HAP80 supplied by the Koiconnect website) equipped with a flowmeter (Hivolin, Germany) to check the flow rate (around $700 \mathrm{~L} / \mathrm{h})$ and the linear speed $\left(<150 \mathrm{~cm} \cdot \mathrm{s}^{-1}\right)$ through the cartridge. Figure 1 summarizes the sampling system.

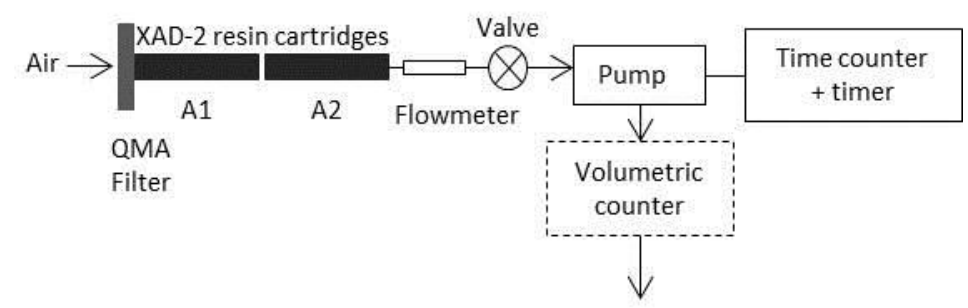

Figure 1. Sampling system for indoor gaseous and particulate phases.

2.3- Extraction. The sorbents, filters and resins were spiked with a mixture of all surrogates the night before the extraction and stored overnight at $4{ }^{\circ} \mathrm{C}$ for the resins and at room temperature in a 
desiccator for the filters. The spiking amounts of surrogate standards are described in the supporting information (Table S-1).

EDC extraction from the resins and filters was performed by ASE. The resins and filters were packed into $34-\mathrm{mL}$ and $5-\mathrm{mL}$ stainless steel cells, respectively, and extracted with a dichloromethane/methanol $(2 / 1 \mathrm{v} / \mathrm{v})$ mixture. The instrument was programmed to operate at $1,500 \mathrm{psi}$ and $100^{\circ} \mathrm{C}$ for 3 static extractions $(5 \mathrm{~min})$ and purging cycles $(120 \mathrm{~s})$. The extracts were evaporated under a gentle stream of nitrogen at $70^{\circ} \mathrm{C}$ up to $500 \mu \mathrm{L}$ of methanol. All the remaining solvent was replaced with $500 \mu \mathrm{L}$ hexane for gas chromatography analysis: evaporation under a gentle stream of nitrogen at $70^{\circ} \mathrm{C}$. Two blank extractions were conducted for each sampling period, one extraction for the gaseous phase matrix and one for the particulate phase matrix, corresponding to extracts obtained from clean XAD-2 resin and a clean QMA filter, respectively. These blanks were analyzed together with the corresponding samples.

2.4- Analytical methods. Some analytical methods were based on those previously described by Alliot et al.[26] and were modified to improve analytical performance.

2.4.1- LC/MS/MS analyses. Chromatographic separation of fourteen compounds was performed on a 1200 liquid chromatograph coupled with a 6410B triple-quadrupole mass spectrometer (Agilent Technologies, Massy, France). The SVOCs analyzed were four parabens (P), methyl-P, ethyl-P, propyl$P$ and butyl-P; two APs, octylphenol (OP) and nonylphenol (NP); four APEOs, octylphenol monoethoxylate, octylphenol diethoxylate, nonylphenol monoethoxylate, and nonylphenol diethoxylate; TBBPA, HBCD, triclosan and BPA. These compounds were separated on an analytical column (Zorbax Eclipse XDB-C18; 4.6 x $50 \mathrm{~mm} ; 1.8 \mu \mathrm{m}$, Agilent Technologies, Les Ulis, France) heated to $50{ }^{\circ} \mathrm{C}$ and equipped with a pre-filter $(2 \mathrm{~mm} ; 0.2 \mu \mathrm{m})$ using a mobile phase gradient of water (solvent A)/methanol (solvent B). The initial conditions were $60 \%$ A. A 10-min gradient was initiated immediately after injection $(10 \mu \mathrm{L})$ until $100 \%$ B was reached; these conditions were maintained for $2 \mathrm{~min}$, and the column was finally stabilized for $5 \mathrm{~min}$ with $60 \% \mathrm{~A}$ (the total run time was $17 \mathrm{~min}$ ). Ammonium hydroxide $(5 \mathrm{mM})$ was added to the mobile phase (solvent $A$ ) for the APs, BPA and APEOs analyses. The operating conditions for LC/MS/MS are detailed in the supporting information (Tables S-2, S-3, S-4 and S-5).

2.4.2- GC/MS analyses. The compounds analyzed by GC/MS were fifteen PAHs, acenaphthylene, acenaphthene, fluorene, phenanthrene, anthracene, fluoranthene, pyrene, benzo(a)anthracene, chrysene, benzo(b)fluoranthene, benzo(k)fluoranthene, benzo(a)pyrene, indeno(c,d)pyrene, dibenzo(a,h)anthracene and benzo(g,h,i)perylene; nine phthalates, dimethylphthalate (DMP), diethylphthalate (DEP), diisobutylphthalate (DiBP), di-n-butylphthalate (DnBP), butylbenzylphthalate (BBP), di(2-ethylhexyl)phthalate (DEHP), di(n-octyl)phthalate (DnOP), diisononylphthalate (DiNP) and diisodecylphthalate (DiDP); two synthetic musks, galaxolide and tonalide; and cypermethrin. Chromatographic separation of the twenty-seven EDCs was performed with a $7890 \mathrm{~A}$ gas chromatograph coupled with a 5975 A mass spectrometer (Agilent Technologies). The system was fitted with a deactivated silica Siltek guard column $(250 \mu \mathrm{m}$ ID) from Restek (Lisses, France) connected to a ZB-5MS analytical column $(30 \mathrm{~m}, 250 \mu \mathrm{m}$ ID $\times 0.25 \mu \mathrm{m}$ film thickness) from Phenomenex (Le Pecq, France). The synthetic musk analysis was based on the Peck and Hornbuckle method[27], with a temperature program modification to reduce analysis time. The operating conditions for the GC/MS analyses are presented in the supporting information (Tables S-6, S-7, S-8 and S-9).

2.4.3- GC/MS/MS analyses. Thirty compounds were analyzed by GC/MS/MS: eight PBDEs, the congeners 28, 47, 99, 100, 153, 154, 183 and 209; nineteen PCBs, the congeners 28, 52, 77, 81, 101, $105,110,114,118,123,126,138,153,156,157,167,169,180$ and 189; HCB, PeCB and lindane. The compounds were separated on a gas chromatograph (Agilent 7890) coupled to a $7000 \mathrm{~B}$ triple quadrupole mass spectrometer with electron impact (EI) ionization (70 eV) (Agilent Technologies) and equipped with a deactivated silica Siltek guard column $(250 \mu \mathrm{m}$ ID) from Restek (Lisses, France) connected to a JW HP-5MS analytical column ( $15 \mathrm{~m}, 250 \mu \mathrm{m}$ ID $\times 0.25 \mu \mathrm{m}$ film thickness) for PBDEs and to a SGE-HT8 analytical column ( $50 \mathrm{~m}, 320 \mu \mathrm{m}$ ID $\times 0.25 \mu \mathrm{m}$ film thickness) for PCBs, HCB, PeCB 
and lindane. Before analysis, the extracts were concentrated to ca. $50 \mu \mathrm{L}$ to improve the sensitivity of the method. The operating conditions for the GC/MS/MS analyses are detailed in the supporting information (Tables S-6, S-10 and S-11).

2.5- Analytical performances. Several performance parameters of the analytical process were evaluated for each analyte from the two atmospheric phases. The sorbents (XAD-2 resin and QMA filter) were spiked the night before extraction and stored overnight at $4{ }^{\circ} \mathrm{C}$ for the resins and at room temperature in a desiccator for the filters. The spiking amounts of the analytes were similar to those found in indoor air and are described in the supporting information (Table S-12). The limit of detection (LOD) and the limit of quantification were considered as the spiking amount (pg) with a signal/noise ratio of 3 and 10, respectively. The LOD and LOQ were calculated on a mass-basis and reported as a concentration $\left(\mathrm{pg} \cdot \mathrm{m}^{-3}\right)$ over the average sample volume $\left(196 \mathrm{~m}^{3}\right)$. They were established for each compound and are indicated in the supporting information (Table S-13). All the quantification limits were below $600 \mathrm{pg} \cdot \mathrm{m}^{-3}$. Phthalates have the higher ones which could be explained by the background contamination issue. The others contaminants have quantification limits under $25 \mathrm{pg} \cdot \mathrm{m}^{-3}$. Quantification was performed by surrogate standard calibration. To evaluate the extraction efficiency, the surrogate standard recoveries were quantified by the addition of internal standards before the analyses. The amounts of internal standard used are detailed in the supporting information (Table S-1). Calibration curves were constructed for each extract analysis. Any $r^{2}$ value from the linear regression curves greater than 0.99 was considered acceptable.

2.6- Presentation of data. Compound concentrations are expressed in $\mathrm{ng} \cdot \mathrm{m}^{-3}$ for the two atmospheric phases. As background contamination is usually an issue with trace levels contaminants, we adopted the following strategy: if the target compound concentration in the sample was not four times higher than blank concentration, a blank correction was performed. No correction was done if the sample concentration was four times higher than the blank. The EDCs concentrations (blank corrected or not) were presented as " $<\mathrm{LOQ}$ " when they were below calculated LOQ. For some compound families, the given concentrations correspond to the sum of the analyzed congener concentrations. These compounds are designated as follows in the results: " $\Sigma 7$ Phthalates", corresponding to the sum of DMP, DEP, DiBP, DnBP, BBP, DEHP and DnOP; " $\Sigma O P+N P$ ", representing the sum of octylphenol and nonylphenol; " $\Sigma$ Ethoxylates", corresponding to the sum of octylphenol monoethoxylate (OP1EO), octylphenol diethoxylate (OP2EO), nonylphenol monoethoxylate (NP1EO) and nonylphenol diethoxylate (NP2EO); " $\Sigma$ Parabens", corresponding to the sum of methyl-P, ethyl-P, propyl-P and butyl-P; " $\Sigma 8$ PAHs-NF" in reference to the 8 PAHs described in the NFX 43-329 AFNOR standard, i.e., benzo(a)pyrene, benzo(b)fluoranthene, benzo(k)fluoranthene, indeno(1,2,3-c,d)pyrene, benzo(a)anthracene, dibenzo(a,h)anthracene, benzo(g,h,i)perylene and fluoranthene; " $\Sigma 6$ PBDEs", representing the sum of PBDE congeners 28,47 , 99, 100, 153, 154; " $\Sigma 7$ PCBs" and " $\Sigma$ DL-PCBs", corresponding to the sum of PCB congeners 28, 52, $101,118,138,153,180$ and to the sum of the dioxin-like PCB congeners $77,81,105,114,118,123$, $126,156,157,167,169,189$, respectively. The concentrations of the other compounds are given individually.

2.7- Uncertainty study by fully nested design. Uncertainty calculation by fully nested design has been described by Maroto et al. [28,29]. This approach estimates the uncertainty of future measurement results using the information from the validation processes using spiked sorbent. The spiked amounts are described in the supporting information (Table S-12). This study does not strictly estimate the uncertainty of a future routine sample because the generated data are related to a test sample. However, if the test sample is homogeneous, stable and representative (i.e., similar to routine samples), then the estimation can be considered significant and can provide uncertainty information for each preprocessing step (spiking, extraction and concentration) and each analytical step (reproducibility and repeatability). In this study, the global uncertainty $(U)$ is defined as the sum of various factors of variation (equation 1)[28]. 


$$
\mathrm{U}=\mathrm{ta}_{/ 2^{2}, v_{\text {eff }}} \times \sqrt{\mathrm{u}_{\text {preprocsteps }}^{2}+\mathrm{u}_{\mathrm{days}}^{2}+\mathrm{u}_{\text {replicates }}^{2}}
$$

where

- $\quad t_{\alpha / 2, \text { veff }}$ is the two-sided Student value at a given $\alpha$ probability and $v_{\text {eff }}$ degrees of freedom (when there are more than a few experimental measurements, $t_{\alpha / 2}$, veff is close to 2 for a probability of $95 \%)$,

- $u_{\text {preproc. steps }}^{2}$ is the uncertainty from preprocessing steps,

- $u_{\text {days }}^{2}$ is the uncertainty from the daily analytical variation,

- $u_{\text {replicates }}^{2}$ is the uncertainty from the analytical variation of the replicates.

To obtain all sources of uncertainty, a fully nested design experiment can be used (Figure 2) to provide an estimate of accuracy for the different studied factors by an analysis of variance (ANOVA) and a calculation of the different variance terms. Because the spiked sorbent (XAD-2 resin or QMA filter) is a major contributing factor and because we expected heterogeneity in the variance decomposition, the analytical measurement uncertainty was determined for each sorbent type separately. The other contributing factors to the uncertainties of the method were the pretreatment step and the inter- and within (replicates)-day measurement variations. For an extract, the analyses were performed on two different days, with two repeat measurements each day. The variances of the different factors were calculated according to published specifications[30,31].

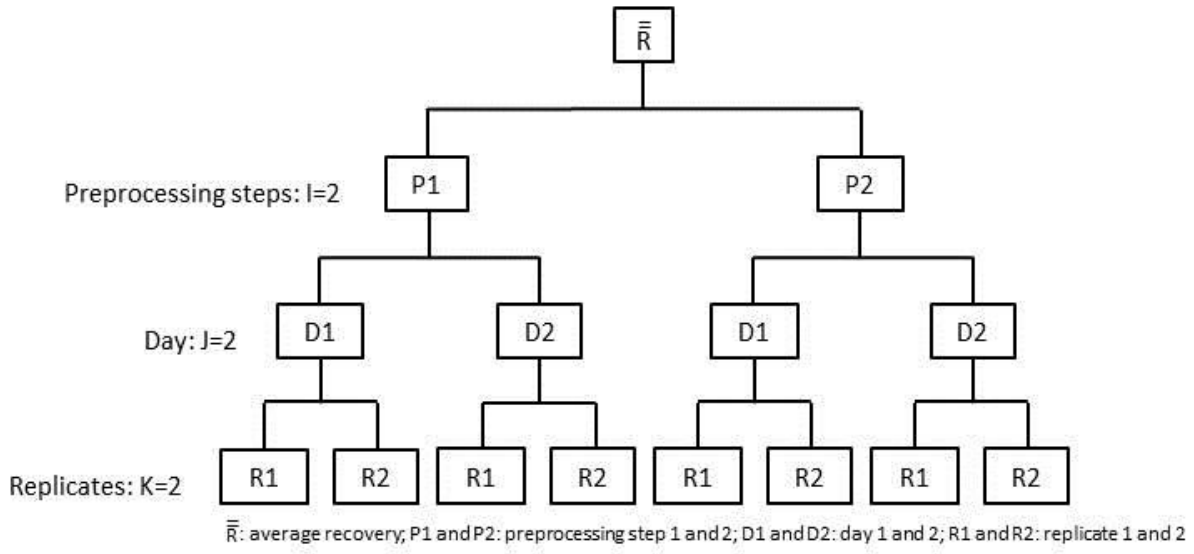

Figure 2. Two-factor fully nested design.

Table 2 shows the ANOVA table and the equations used for the uncertainty calculations. The recovery rates of the compounds were estimated for each extraction sorbent spiked by two different operators. For any sorbent, the global uncertainty was calculated from equation 1 . Uncertainties were calculated on a mass-basis and converted to a concentration $\left(\mathrm{ng} \cdot \mathrm{m}^{-3}\right)$ over the average sample volume $\left(196 \mathrm{~m}^{3}\right)$ for all EDCs.

Table 2. ANOVA table for fully nested experimental design and method of uncertainty calculation.

\begin{tabular}{ccccc} 
Source & Level & $\begin{array}{c}\text { Mean squares } \\
(\mathrm{MS})\end{array}$ & Uncertainty $\left(\mathrm{u}^{2}\right)$ & $\begin{array}{c}\text { Degrees of } \\
\text { freedom }\end{array}$ \\
\hline $\begin{array}{c}\text { Preprocessing } \\
\text { steps }\end{array}$ & $\mathrm{I}=2$ & $\frac{\mathrm{J} \times \mathrm{K} \times\left(\sum_{\mathrm{i}=1}^{2}\left(\overline{\mathrm{x}}_{\mathrm{i}}-\overline{\overline{\mathrm{x}}}\right)^{2}\right)}{\mathrm{I}-1}$ & $\frac{\mathrm{MS}_{\text {preprocessing steps }}-\mathrm{MS}_{\mathrm{day}}}{\mathrm{J} \times \mathrm{K}}$ & $\mathrm{I}-1$ \\
Day & $\mathrm{J}=2$ & $\frac{\mathrm{K} \times\left(\sum_{\mathrm{i}=1}^{2} \sum_{\mathrm{j}=1}^{2}\left(\overline{\mathrm{x}}_{\mathrm{ij}}-\overline{\mathrm{x}}_{\mathrm{i}}\right)\right.}{\mathrm{I} \times(\mathrm{J}-1)}$ & $\frac{\mathrm{MS}_{\mathrm{day}}-\mathrm{MS}_{\text {replicates }}}{\mathrm{K}}$ & $\mathrm{I} \times(\mathrm{J}-1)$
\end{tabular}




\section{3- RESULTS AND DISCUSSION}

3.1- Sampling and extraction efficiency. The sorbent materials, XAD-2 resin and QMA filter, were selected based on their frequent use in SVOC studies [25,32,33]. Moreover, Chuang et al. [34] have demonstrated that the efficiency of XAD-2 resin is higher than that of polyurethane foam (PUF) for PAHs, which have physical properties similar to those of the target SVOCs.

The assessment of the sorbents ability to retain target compounds from atmospheric phases was carried out, by comparing two sampling flow rates on the one hand, and on the other hand, by estimating relative retention efficiency between two serial XAD-2 resins cartridges in comparison with that of the QMA filter. Both studies were conducted in the office.

The impact of the flow rate on sorbents efficiency to retain EDCs is first presented. Gaseous and particulate phases were collected with two sampling systems operating simultaneously at different flow rates, 686 and $319 \mathrm{~L} / \mathrm{h}$, chosen to study the interest of working with medium volumes compared to low volumes usually employed in the literature. XAD-2 resins and QMA filters were then analyzed to evaluate their content in contaminants reported in $\mathrm{ng} \cdot \mathrm{m}^{-3}$ for gaseous and particulate phases, respectively (Table 3 and Table S-14). Whatever the flow rate used, the EDCs concentrations in the two atmospheric phases were in the same order of magnitude, in general. The highest flow rate allowed the quantification of galaxolide and nonylphenol at large concentrations in gaseous phase. But the particulate phase concentrations were the same for the two flow rates, suggesting no breakthrough from the QMA filter to the XAD-2 resin of these compounds. This observation may therefore be the consequence of a point source contamination by scented products during the sampling period, more quickly integrated by the medium flow system than by the lower one before its atmospheric dispersion. The similar differences in concentrations found between the two-sampler flow rates for nonylphenol in the gaseous phase suggest the detergent nature of the involved products. Cypermethrin concentrations in particulate phase were larger when using the lowest flow rate. It was not possible to be sure that the cypermethrin was at least partially breakthrough to the XAD-2 resin. These results show that the flow rates and the sorbents used for the sampling were adapted to the target contaminants.

Table 3. EDC concentrations (in ng. $\mathrm{m}^{-3}$ ) in gaseous and particulate phases from the office according to sampling flow rates.

\begin{tabular}{|c|c|c|c|c|}
\hline \multirow[t]{2}{*}{ Compound } & \multicolumn{2}{|c|}{$\begin{array}{l}\text { Flow rate: } 319 \mathrm{~L} / \mathrm{h} \\
\text { Linear speed: } 67 \mathrm{~cm} / \mathrm{s}\end{array}$} & \multicolumn{2}{|c|}{$\begin{array}{l}\text { Flow rate: } 686 \mathrm{~L} / \mathrm{h} \\
\text { Linear speed: } \\
144 \mathrm{~cm} / \mathrm{s}\end{array}$} \\
\hline & $\begin{array}{l}\text { Gaseous } \\
\text { phase }\end{array}$ & $\begin{array}{l}\text { Particu } \\
\text { late phase }\end{array}$ & $\begin{array}{c}\text { Gaseous } \\
\text { phase }\end{array}$ & $\begin{array}{r}\text { Partic } \\
\text { ulate phase }\end{array}$ \\
\hline & $\begin{array}{l}\text { Phthal } \\
\text { ates }\end{array}$ & & & \\
\hline DEHP & 8,239 & 92,27 & 4,839 & 84,15 \\
\hline$\sum 7$ Phthalates & $\begin{array}{r}265,5 \\
\text { Musks }\end{array}$ & 231,3 & 216,6 & 191,4 \\
\hline Galaxolide & 6,566 & 0,387 & 21,71 & 0,322 \\
\hline Tonalide & $\begin{array}{l}\text { 3,046 } \\
\text { Alkylph } \\
\text { enols }\end{array}$ & 0,069 & 4,701 & 0,053 \\
\hline Octylphenol & 2,856 & 0,139 & 3,933 & 0,102 \\
\hline
\end{tabular}




\begin{tabular}{|c|c|c|c|c|}
\hline Nonylphenol & 12,85 & 0,368 & 24,99 & 0,301 \\
\hline$\Sigma \mathrm{OP}+\mathrm{NP}$ & 15,70 & 0,507 & 28,92 & 0,403 \\
\hline OP1EO & 0,596 & 0,037 & 0,975 & 0,041 \\
\hline OP2EO & 0,002 & 0,017 & 0,003 & 0,015 \\
\hline NP1EO & 2,799 & 0,928 & 4,402 & 1,001 \\
\hline NP2EO & 0,274 & 0,289 & 0,095 & 0,503 \\
\hline \multirow[t]{3}{*}{$\sum$ Ethoxylates } & 3,672 & 1,270 & 5,475 & 1,561 \\
\hline & Phenol & & & \\
\hline & & & & \\
\hline Bisphenol A & 0,068 & 0,390 & 0,023 & 0,521 \\
\hline \multirow[t]{3}{*}{ TBBPA } & - & 0,020 & - & 0,028 \\
\hline & Parabe & & & \\
\hline & & & & \\
\hline Methyl-P & 1,874 & 0,116 & 2,406 & 0,140 \\
\hline Ethyl-P & 0,091 & 0,003 & 0,125 & 0,005 \\
\hline Propyl-P & 0,524 & 0,023 & 0,969 & 0,027 \\
\hline Butyl-P & 0,030 & 0,005 & 0,054 & 0,005 \\
\hline \multirow[t]{2}{*}{$\sum 4$ Parabens } & 2,519 & 0,147 & 3,555 & 0,176 \\
\hline & PAHs & & & \\
\hline Phenanthrene & 90,17 & 0,125 & 90,08 & 0,152 \\
\hline Benzo(a)pyrene & 0,067 & 0,217 & 0,057 & 0,309 \\
\hline \multirow[t]{3}{*}{$\sum 8 \mathrm{PAH}-\mathrm{NF}$} & 11,69 & 1,832 & 10,82 & 2,452 \\
\hline & Pestici & & & \\
\hline & & & & \\
\hline Cypermethrin & 2,146 & 27,189 & 2,403 & 5,479 \\
\hline \multirow[t]{2}{*}{ Lindane } & 0,88 & 0,012 & 0,62 & 0,010 \\
\hline & PCBs & & & \\
\hline $\mathrm{HCB}$ & 1,246 & 0,001 & 1,151 & 0,001 \\
\hline PeCB & 1,410 & 0,001 & 1,223 & 0,001 \\
\hline$\sum 7 \mathrm{PCB}$ & 2,858 & 0,053 & 3,733 & 0,049 \\
\hline \multirow[t]{2}{*}{$\sum \mathrm{DL}-\mathrm{PCB}$} & 0,125 & 0,004 & 0,154 & 0,003 \\
\hline & PBDES & & & \\
\hline PBDE 47 & 0,057 & 0,010 & 0,089 & 0,012 \\
\hline \multirow[t]{2}{*}{$\sum 6 \mathrm{BDE}$} & 0,076 & 0,044 & 0,115 & 0,051 \\
\hline & Others & & & \\
\hline $\mathrm{HBCD}$ & 0,000 & 0,001 & 0,000 & 0,001 \\
\hline Triclosan & 0,224 & 0,052 & 0,416 & 0,072 \\
\hline
\end{tabular}

For the other study, integrated air sampling was performed over 15 days with two serial XAD-2 resin cartridges ( $A 1$ and $A 2$ ) and a QMA filter for the sampling of the gaseous phase and the particulate phase, respectively. The retention efficiency of the XAD-2 resin in the first cartridge $A 1$ was assessed by comparing the target EDCs content of the two cartridges and the QMA filter. The majority of the SVOCs of interest were retained on the first cartridge A1, which adsorbed an average of $81 \%$ of the trapped compounds (Figure 3), particularly the most volatile compounds: parabens, triclosan, APs, alkylphenols monoethoxylates (AP1EO), synthetic musks, volatiles phthalates, semivolatiles PAHs, PBDE 47, PeCB, HCB, lindane and volatiles PCBs. The less volatiles compounds were mainly present in the particulate phase and retained by the QMA filter: HBCD, BPA, NP2EO, 
cypermethrin, non-volatiles phthalates and non-volatiles PCBs. Sixty percent of PBDE 99 and the nonvolatiles PAHs were held on the QMA filter and the remaining was mainly adsorbed on the first XAD cartridge (A1). Since DnOP, OP2EO, PBDE 28, PBDE 100, PBDE 153 and PBDE 154 presented concentrations below their LOQs, their distribution between adsorbents could not be established. The percentages of the retained amounts by the different sorbents and the vapor pressures are detailed for each compound in the supporting information (Table S-15).

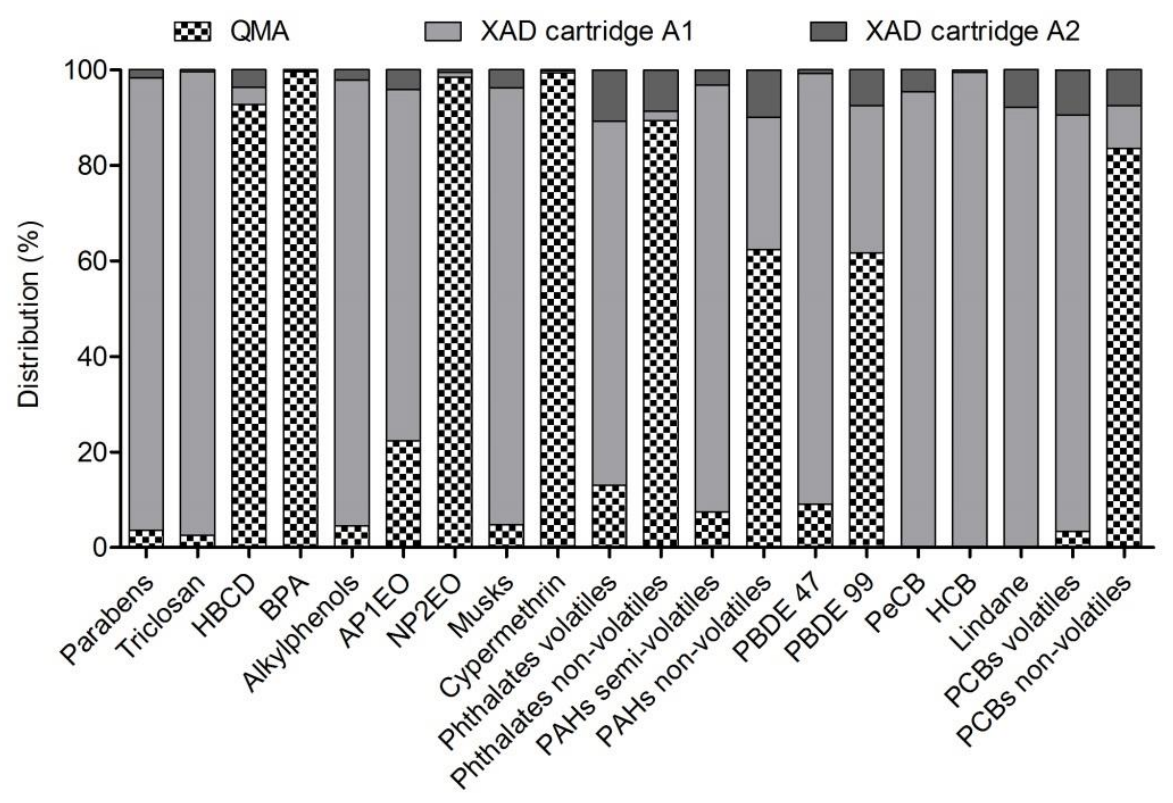

Figure 3. Distribution of the compound amounts retained on the two XAD-2 resin cartridges and the QMA filter.

Furthermore, the extraction efficiency of the analytes from the two sorbents, XAD-2 resin and QMA filter, was determined by a recovery study using spiked sorbents containing all target EDCs. The spiking amounts used are detailed in the supporting information (Table S-12). Recovery assays demonstrated satisfactory results with respect to the contaminant concentrations studied in indoor air. The median recovery rates of the compounds were $98.6 \%$ and $98.3 \%$ from the XAD-2 resin and the QMA filter, respectively (Figure 4). Some analytes (acenaphthtylene, acenaphthene, fluorene, and $\mathrm{PeCB}$ ) might have been lost during the concentration step because of their volatility, resulting in recovery levels below $70 \%$. Since the low recovery rate of HBCD could not be explained by its volatility, the assumption is a not well extraction of this compound from the two sorbents. DiNP could not be accurately quantified. Less than $10 \%$ of the spiking amounts were detected in the extraction of the blanks, which is consistent with contamination levels in indoor air. TBBPA extraction from the XAD-2 resin was not possible under the ASE conditions used. The recovery rates for each compound in each atmospheric phase are presented in the supporting information (Table S-13). 


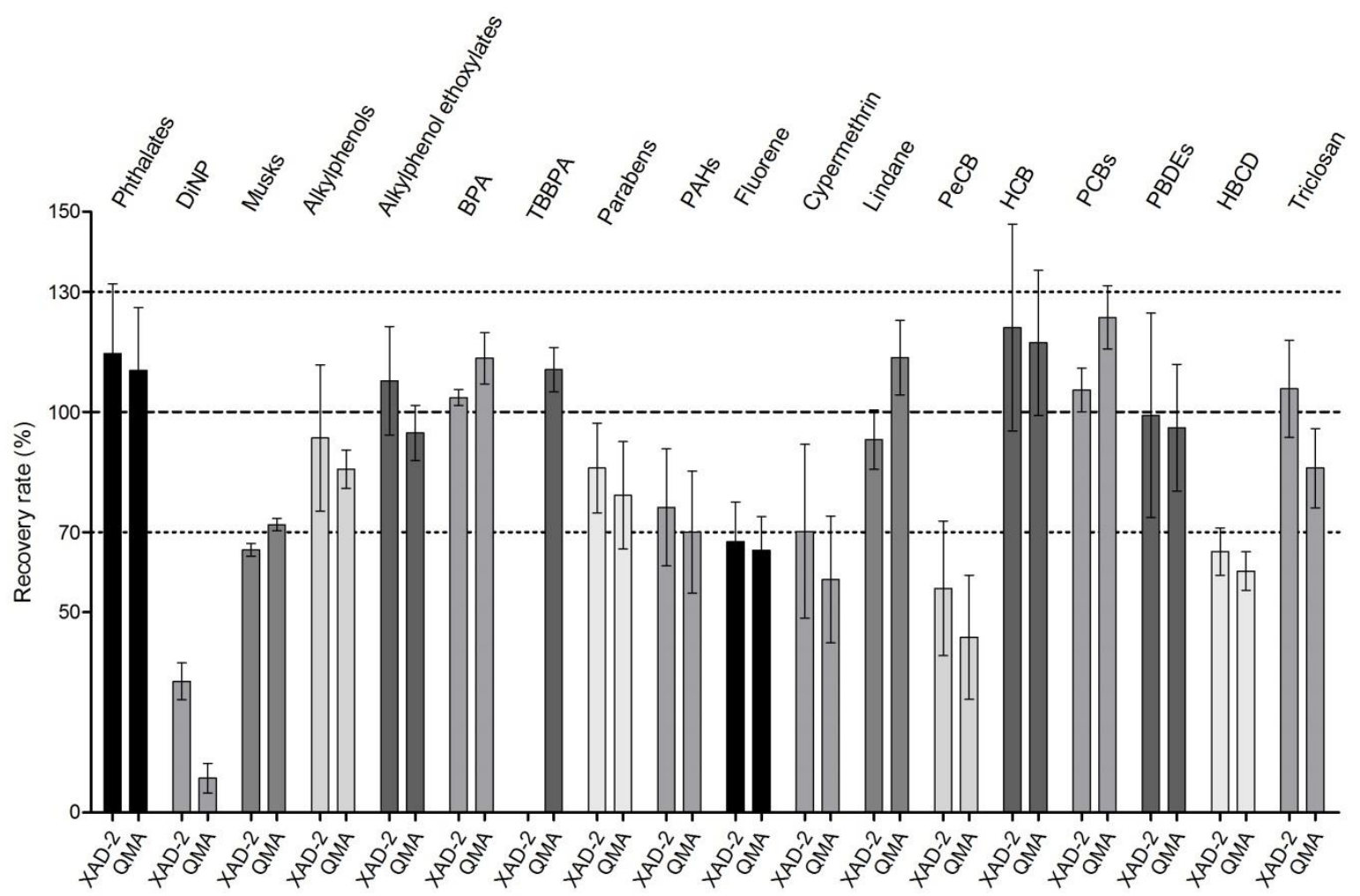

Figure 4. Efficiency extraction of target compounds from the two sorbents (XAD-2 resin and QMA filter).

3.2- Analytical measurement uncertainty. The results of the uncertainty analysis are summarized for every group of compounds in Table 4 and detailed in the supporting information (Table S-16). The values obtained in the uncertainty study were lower than the mean concentration levels found in indoor air presented in the next section (Table 5).

Table 4. Global uncertainty of target compounds measurement evaluated by the fully nested experiment.

\begin{tabular}{ccc}
\hline & \multicolumn{2}{c}{ Uncertainty $\left(\mathrm{ng} \cdot \mathrm{m}^{-3}\right)$} \\
\cline { 2 - 3 } Compound & $\begin{array}{c}\text { Gaseous } \\
\text { phase }\end{array}$ & $\begin{array}{c}\text { Particulate } \\
\text { phase }\end{array}$ \\
\hline Phthalates & 4.64 & 4.91 \\
Synthetic musks & 0.07 & 0.06 \\
Alkylphenols & 0.13 & 0.29 \\
Alkylphenols ethoxylates (except & 0.03 & 0.05 \\
OP2EO) & 0.17 & 0.11 \\
OP2EO & 0.62 & 1.28 \\
BPA & - & 0.18 \\
TBBPA & 0.09 & 0.07 \\
Parabens & 0.24 & 0.29 \\
PAHs & &
\end{tabular}




\begin{tabular}{cll} 
Lindane & 0.15 & 0.09 \\
PeCB & 0.34 & 0.08 \\
HCB & 0.04 & 0.11 \\
PCBs & 0.10 & 0.22 \\
PBDEs & 0.05 & 0.03 \\
HBCD & 0.02 & 0.01 \\
Triclosan & 0.02 & 0.02 \\
\hline
\end{tabular}

3.3- Application of the analytical method. The overall validated analytical protocol (sampling, extraction and chromatographic analysis) was then applied to the characterization of indoor air contamination by the target EDCs. Gaseous and particulate phases from four indoor locations (day nursery, house, office, and apartment) were collected during summer 2013 over three consecutives periods of 15 days, and their EDC content was analyzed (Table 5). The results were compared to the literature to evaluate the developed protocol efficiency. The compound concentrations in the gaseous and particulate phases are detailed in the supporting information (Table S-17).

Table 5. EDC concentrations in gaseous and particulate phases collected indoors in summer 2013. Each value, expressed as $\mathrm{ng} \cdot \mathrm{m}^{-3}$, corresponds to the mean of three successive samplings (mean $\pm S D, n=3$ ).

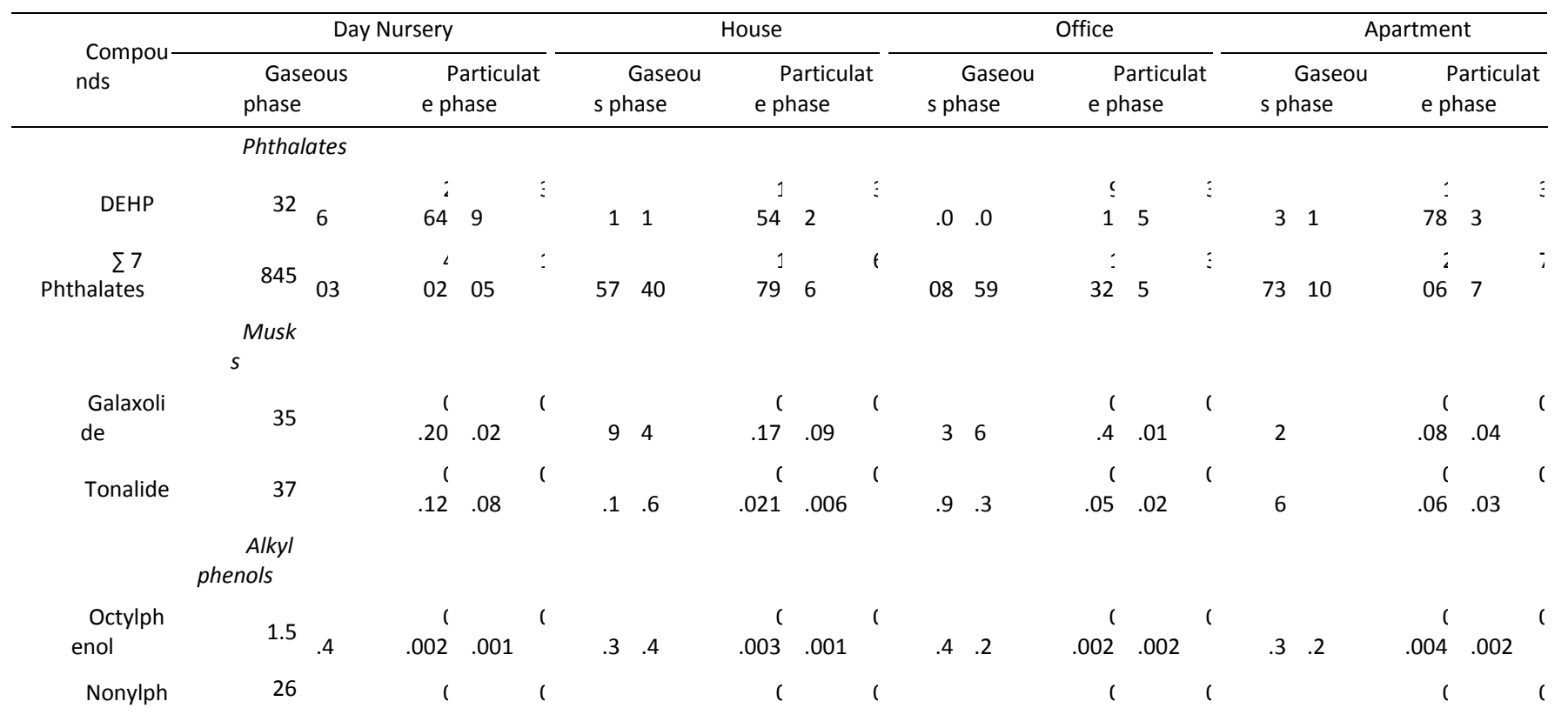




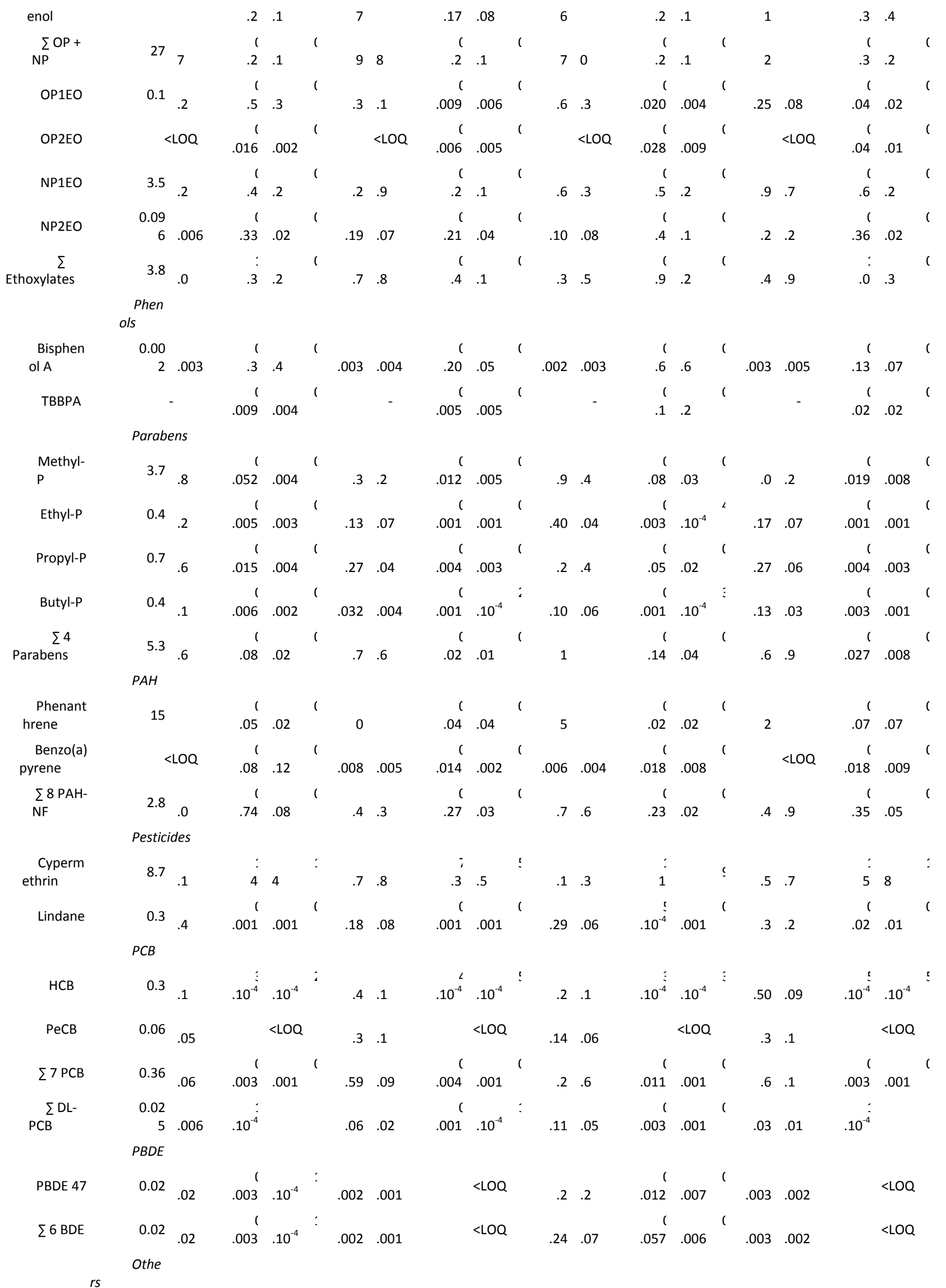




\begin{tabular}{|c|c|c|c|c|c|c|c|c|c|c|c|c|c|c|c|c|c|}
\hline $\mathrm{HBCD}$ & $\begin{array}{ll}1.10^{-} & \\
& \\
& \end{array}$ & .001 & $.10^{-4}$ & $\vdots$ & .002 & .003 & .001 & $.10^{-4}$ & $.10^{-4}$ & $.10^{-4}$ & & $.10^{-4}$ & & $.10^{-4}$ & .001 & $.10^{-4}$ & $.10^{-4}$ \\
\hline $\begin{array}{l}\text { Triclosa } \\
\mathrm{n}\end{array}$ & $0.06 \quad .04$ & $\begin{array}{r}( \\
.007\end{array}$ & .002 & ( & .09 & .03 & .013 & .007 & .21 & .04 & $.022^{\prime}$ & .005 & ( & .14 & .02 & $\begin{array}{r}( \\
.018\end{array}$ & .006 \\
\hline
\end{tabular}

Phthalates were the most abundant indoor air contaminants, with air concentration (gaseous and particulate phases) concentrations ranging from 839 to $1,246 \mathrm{ng} \cdot \mathrm{m}^{-3}$. Phthalates concentrations were highest in the day nursery. The $\Sigma 7$ phthalates (DMP, DEP, DiBP, DnBP, BBP, DEHP and DnOP) were primarily concentrated in the gas phase (approximately $78 \%$ ), and most of the DEHP was present in the particulate phase (90\% on average). Gas/particle partitioning of the different phthalates and their indoor concentration levels were close to those reported in American and French houses[35,36].

The synthetic musks were primarily concentrated in the day nursery and in the house, with levels of approximately $70 \mathrm{ng} \cdot \mathrm{m}^{-3}$ compared to $40 \mathrm{ng} \cdot \mathrm{m}^{-3}$ on average in the other two locations. Because of their high volatility, musks were nearly exclusively present in the gaseous phase $199 \%$ on average). The contaminant profiles of the atmospheric phases were similar for galaxolide and tonalide in the day nursery and apartment, while only galaxolide was predominant in the house and office. Higher musk concentrations were reported in German nurseries (median of $101 \mathrm{ng} \cdot \mathrm{m}^{-3}$ and $41 \mathrm{ng} \cdot \mathrm{m}^{-3}$ for galaxolide and tonalide, respectively)[37] and Spanish apartments (143 to $1,129 \mathrm{ng} \cdot \mathrm{m}^{-3}$ for galaxolide and 21 to $77 \mathrm{ng} \cdot \mathrm{m}^{-3}$ for tonalide)[38].

The third abundant EDC group was APs ( $21 \mathrm{ng} \cdot \mathrm{m}^{-3}$ on average). Among the APs, NP was predominant, accounting for 89 to $95 \%$ of indoor AP concentrations. NP remains the most produced $A P$, representing $80 \%$ of global AP production[39]. The house and day nursery were most contaminated by APs, with an average of $28 \mathrm{ng} \cdot \mathrm{m}^{-3}$ versus $15 \mathrm{ng} \cdot \mathrm{m}^{-3}$ for the apartment and office. APEO concentrations were lower than those of APs $\left(6.4 \mathrm{ng} \cdot \mathrm{m}^{-3}\right.$ on average); their major indoor representative was NP1EO $\left(5.48 \mathrm{ng} \cdot \mathrm{m}^{-3}\right)$. Conversely, low concentrations were quantified for the diethoxylate species (NP2EO and OP2EO), which were present at 0.47 and $0.02 \mathrm{ng} \cdot \mathrm{m}^{-3}$, respectively. All APs and APEOs were primarily concentrated in the gaseous phase, contributing $99 \%$ and $85 \%$ of the total, respectively. The AP and APEO concentrations in indoor air were similar to those reported for California homes (median of 53 and $20 \mathrm{ng} \cdot \mathrm{m}^{-3}$ for NP and NP1EO)[40], American homes (110, 17 and $8.6 \mathrm{ng} \cdot \mathrm{m}^{-3}$ for NP, NP1EO and octylphenol monoethoxylate, respectively)[35] and Japanese homes and offices (3.7 and $53.2 \mathrm{ng} \cdot \mathrm{m}^{-3}$ for OP and NP, respectively)[41].

Because of its null extraction yield on XAD-2 resin, the TBBPA concentrations were determined only in the particulate phase, with values ranging from 5 to $117 \mathrm{pg} \cdot \mathrm{m}^{-3}$. These data are comparable with those in the literature. TBBPA was reported at concentrations of approximately $20 \mathrm{pg} \cdot \mathrm{m}^{-3}$ in fourteen American dwelling places[42], at $15 \mathrm{pg} \cdot \mathrm{m}^{-3}$ in five English houses and at $11 \mathrm{pg} \cdot \mathrm{m}^{-3}$ in five English offices [6].

BPA was primarily present in the particulate phase at concentrations from 129 to $560 \mathrm{pg} \cdot \mathrm{m}^{-3}$. Comparable levels of BPA were observed in France, with $537 \mathrm{pg} \cdot \mathrm{m}^{-3}$ in apartments and $465 \mathrm{pg} \cdot \mathrm{m}^{-3}$ in offices[36]; those observed in American houses were lower than the LOQ value $\left(800 \mathrm{pg} \cdot \mathrm{m}^{-3}\right)$ [40].

Paraben concentrations varied according to the type of living space and were higher in the office $\left(10.74 \mathrm{ng} \cdot \mathrm{m}^{-3}\right)$ and day nursery $\left(5.40 \mathrm{ng} \cdot \mathrm{m}^{-3}\right)$ than the apartment $\left(2.58 \mathrm{ng} \cdot \mathrm{m}^{-3}\right)$ and house $\left(1.73 \mathrm{ng} \cdot \mathrm{m}^{-3}\right)$. The primary use of parabens as bactericides or preservatives can explain their high levels in collective locations. Up to $98 \%$ of parabens were present in the gaseous phase. The major paraben was methyl-P $\left(3.76 \mathrm{ng} \cdot \mathrm{m}^{-3}\right.$ on average) because of its high volatility $\left(3.16 \times 10^{-2} \mathrm{~Pa}\right.$ at $\left.25^{\circ} \mathrm{C}\right)$, followed by propyl-P $\left(0.89 \mathrm{ng} \cdot \mathrm{m}^{-3}\right)$, ethyl-P $\left(0.29 \mathrm{ng} \cdot \mathrm{m}^{-3}\right)$ and butyl-P $\left(0.18 \mathrm{ng} \cdot \mathrm{m}^{-3}\right)$. In an American study of 120 houses, ethyl-P and butyl-P concentrations were below their LOD, while methyl-P was detected at similar levels, with a median concentration of $2.9 \mathrm{ng} \cdot \mathrm{m}^{-3}$ [35].

Air contamination by PAHs ( $\Sigma 8$ PAHs-NF) was higher in the office $\left(4.90 \mathrm{ng} \cdot \mathrm{m}^{-3}\right)$ than in the house $\left(3.69 \mathrm{ng} \cdot \mathrm{m}^{-3}\right)$, day nursery $\left(3.55 \mathrm{ng} \cdot \mathrm{m}^{-3}\right)$ or apartment $\left(2.70 \mathrm{ng} \cdot \mathrm{m}^{-3}\right)$. This result may be 
attributable to more frequent opening of windows in the office, a source of PAHs of outdoor origin $[43,44]$. PAHs were primarily present in the gaseous phase, with an average value of $88 \%$ ( $\Sigma 8$ PAHs-NF). Air concentrations of phenanthrene ranged from 15.06 to $22.27 \mathrm{ng} \cdot \mathrm{m}^{-3}$ and were similar to those found indoors in American houses (11 ng. $\mathrm{m}^{-3}$ in median)[40]. Benzo(a)pyrene was primarily present in the particulate phase at low concentrations (from $14 \mathrm{pg} \cdot \mathrm{m}^{-3}$ in the house to $82 \mathrm{pg} \cdot \mathrm{m}^{-3}$ in the day nursery).

Of the two pesticides analyzed, cypermethrin was 4 to 90 times more concentrated in indoor ambient air than lindane (17.24 versus $1.51 \mathrm{ng} \cdot \mathrm{m}^{-3}$ on average). Cypermethrin was primarily present in the particulate phase $(70 \%)$, while lindane was predominant in the gaseous phase $(99 \%)$. Cypermethrin contamination was highest in the day nursery and apartment $\left(22.88\right.$ and $19.49 \mathrm{ng} \cdot \mathrm{m}^{-3}$, respectively). These relatively high levels might be related to the use of anti-cockroach products in the day nursery and insecticide products for wood furniture in the apartment. The highest concentrations of lindane in the apartment $\left(5.34 \mathrm{ng} \cdot \mathrm{m}^{-3}\right)$ might also be due to the use of insecticide products for wood furniture before its European ban in 2007. The presence of cypermethrin and lindane has been detected in the ambient air of American houses but at median concentrations lower than the LOQ $\left(1 \mathrm{ng} \cdot \mathrm{m}^{-3}\right)[35]$.

$\mathrm{HCB}$ and PeCB were detected at low concentrations in the four locations (mean values of 353 and $196 \mathrm{pg} \cdot \mathrm{m}^{-3}$, respectively). These two compounds were exclusively present in the gaseous phase. Only two studies of indoor air levels of HCB and PeCB have been published. Compared to our data, lower HCB concentrations were observed in Mexican, English and Sweden houses (54, 67 and $150 \mathrm{pg} \cdot \mathrm{m}^{-3}$ respectively),[45] and lower PeCB concentrations were measured on a Czech university campus $\left(4.07 \mathrm{pg} \cdot \mathrm{m}^{-3}\right)[46]$.

The $\Sigma 7$ PCBs concentrations were higher in the office $\left(2.25 \mathrm{ng} \cdot \mathrm{m}^{-3}\right)$ than in the three other sites $\left(0.51 \mathrm{ng} \cdot \mathrm{m}^{-3}\right.$ in average). PCB 52 was the predominant compound in indoor air because of its high volatility $\left(1.13 \times 10^{-3} \mathrm{~Pa}\right.$ at $\left.25^{\circ} \mathrm{C}\right)$. The concentrations of $\Sigma \mathrm{DL}$-PCBs were nearly 10 times lower than those of $\Sigma 7$ PCBs. All of these PCBs were largely quantified in the gaseous phase. The contamination levels of these PCBs were consistent with those reported in the indoor air of public locations in English offices $\left(5.9 \mathrm{ng} \cdot \mathrm{m}^{-3}\right.$ in median)[47] and 20 indoor locations in Canada $\left(8.5 \mathrm{ng} \cdot \mathrm{m}^{-3}\right.$ in median)[48].

PBDEs were primarily present in the office $\left(294 \mathrm{pg} \cdot \mathrm{m}^{-3}\right.$ for $\Sigma$ PBDEs) compared with the other dwelling places $\left(10 \mathrm{pg} \cdot \mathrm{m}^{-3}\right.$ on average). PBDE 47 was the major representative, accounting for approximately $100 \%$ (day nursery, house and apartment) or $60 \%$ (office) of the indoor air contamination by $\Sigma$ PBDEs. PBDE 183 and PBDE 209 could not be quantified. These results are in accordance with contamination data for PBDEs in American houses (455 pg. $\mathrm{m}^{-3}$ in average)[49] and English locations (71 pg. $\mathrm{m}^{-3}$ in offices and $24 \mathrm{pg} \cdot \mathrm{m}^{-3}$ in homes)[47].

HBCD concentrations were too low (from 0.7 to $3 \mathrm{pg} \cdot \mathrm{m}^{-3}$ ) for a comparison between sites or atmospheric phases. Higher concentrations in HBCD were measured in houses $\left(180 \mathrm{pg} \cdot \mathrm{m}^{-3}\right)$, offices $\left(170 \mathrm{pg} \cdot \mathrm{m}^{-3}\right)$ and public places $\left(900 \mathrm{pg} \cdot \mathrm{m}^{-3}\right)$ in England [6].

Triclosan concentrations varied according to location. The office was the most contaminated site $\left(230 \mathrm{pg} \cdot \mathrm{m}^{-3}\right)$, followed by the apartment $\left(153 \mathrm{pg} \cdot \mathrm{m}^{-3}\right)$, house $\left(104 \mathrm{pg} \cdot \mathrm{m}^{-3}\right)$ and day nursery $\left(68 \mathrm{pg} \cdot \mathrm{m}^{-3}\right)$. No other study is available in the literature to enable a comparison of data.

\section{CONCLUSIONS}

The analytical methodology developed is the first that allows simultaneous extraction, identification, and quantification of a wide variety of EDCs in the two atmospheric phases (gaseous and particulate) of indoor air. The accuracy and the precision of the analytical protocol gave satisfactory results with respect to the indoor air concentrations. Certain contaminants were not quantified with precision because of their high volatility (acenaphthtylene, acenaphthene, fluorene, $\mathrm{HCB}$ and PeCB) or certain analytical difficulties (DiNP). TBBPA could only be extracted and quantified from the particulate phase. The analytical methods developed were used to investigate EDC behavior in ambient air. Of all the 69 EDCs initially considered, the methodology was not sufficiently efficient 
for only these 7 compounds. Overall, it has enabled the quantification of EDCs even at very low levels in indoor air, including fluorene, $\mathrm{PeCB}, \mathrm{DiNP}$ and $\mathrm{HBCD}$ in the gaseous phase and in the particulate phase for the last two compounds. The analyzed EDCs were primarily present in the gaseous phase. Triclosan was quantified in indoor air for the first time. The house and day nursery were the most contaminated locations. At these sites, phthalates, synthetic musks, APs and parabens were the most abundant compounds. These results are in accordance with international literature and previous studies for similar locations[11,26]. The overall analytical protocol will be used for future studies of seasonal variations of indoor air contamination and will be associated with in vitro biological assays to evaluate the endocrine-disrupting potential of indoor air.

\section{ACKNOWLEDGMENTS}

This study was supported by the lle-de-France region.

\section{REFERENCES}

[1] T. Colborn, F.S. vom Saal, A.M. Soto, Developmental effects of endocrine-disrupting chemicals in wildlife and humans., Environ. Health Perspect. 101 (1993) 378-384.

[2] S.H. Safe, Endocrine disruptors and human health-is there a problem? An update., Environ. Health Perspect. 108 (2000) 487.

[3] R.L. Cooper, R.J. Kavlock, Endocrine disruptors and reproductive development: a weight-ofevidence overview, J. Endocrinol. 152 (1997) 159-166.

[4] K. Cailleaud, J. Forget-Leray, S. Souissi, S. Lardy, S. Augagneur, H. Budzinski, Seasonal variation of hydrophobic organic contaminant concentrations in the water-column of the Seine Estuary and their transfer to a planktonic species Eurytemora affinis (Calanoïd, copepod). Part 2: Alkylphenol-polyethoxylates, Chemosphere. 70 (2007) 281-287.

[5] M. Chevreuil, Agence de l'eau Seine-Normandie, Programme interdisciplinaire de recherche sur l'environnement de la Seine, La micropollution organique dans le bassin de la Seine : maîtriser l'impact des molécules créées par l'homme, Agence de l'eau Seine-Normandie, 2009.

[6] M.A.E. Abdallah, S. Harrad, A. Covaci, Hexabromocyclododecanes and tetrabromobisphenol-A in indoor air and dust in Birmingham, UK: implications for human exposure, Environ. Sci. Technol. 42 (2008) 6855-6861.

[7] A. Albinet, E. Leoz-Garziandia, H. Budzinski, E. Villenave, Polycyclic aromatic hydrocarbons (PAHs), nitrated PAHs and oxygenated PAHs in ambient air of the Marseilles area (South of France): Concentrations and sources, Sci. Total Environ. 384 (2007) 280-292.

[8] G. ten Dam, O. Pardo, W. Traag, M. van der Lee, R. Peters, Simultaneous extraction and determination of HBCD isomers and TBBPA by ASE and LC-MSMS in fish, J. Chromatogr. B. 898 (2012) 101-110. doi:10.1016/j.jchromb.2012.04.025.

[9] J.E. Biles, T.P. McNeal, T.H. Begley, H.C. Hollifield, Determination of Bisphenol-A in Reusable Polycarbonate Food-Contact Plastics and Migration to Food-Simulating Liquids, J. Agric. Food Chem. 46 (1998) 2894-2894.

[10] L.A. Wallace, E.D. Pellizzari, T. D.Hartwell, C.M. Sparacino, L.S. Sheldon, H. Zelon, Personal exposures, indoor-outdoor relationships, and breath levels of toxic air pollutants measured for 355 persons in New Jersey, Atmospheric Environ. 1967. 19 (1985) 1651-1661. doi:10.1016/0004-6981(85)90217-3.

[11] E. Moreau-Guigon, M. Chevreuil, L'exposition humaine aux perturbateurs endocriniens via l'air ambiant: un risque sanitaire méconnu, Arch. Mal. Prof. Environ. 75 (2014) 74-81. doi:10.1016/j.admp.2013.09.050.

[12] C.J. Weschler, Changes in indoor pollutants since the 1950s, Atmos. Environ. 43 (2009) 153169. doi:10.1016/j.atmosenv.2008.09.044.

[13] R.A. Rudel, L.J. Perovich, Endocrine disrupting chemicals in indoor and outdoor air, Atmos. Environ. 43 (2009) 170-181. 
[14] IPCS/WHO, Global assessment of the state-of-the-science of endocrine disruptors WHO/PCS/EDC/02.2,

2002.

http://www.who.int/ipcs/publications/new_issues/endocrine_disruptors/en/ (accessed July 15, 2013).

[15] V. Christen, P. Crettaz, A. Oberli-Schrämmli, K. Fent, Some flame retardants and the antimicrobials triclosan and triclocarban enhance the androgenic activity in vitro, Chemosphere. 81 (2010) 1245-1252. doi:10.1016/j.chemosphere.2010.09.031.

[16] P.O. Darnerud, Brominated flame retardants as possible endocrine disrupters, Int. J. Androl. 31 (2008) 152-160. doi:10.1111/j.1365-2605.2008.00869.x.

[17] S.C. Laws, S.A. Carey, J.M. Ferrell, G.J. Bodman, R.L. Cooper, Estrogenic Activity of Octylphenol, Nonylphenol, Bisphenol A and Methoxychlor in Rats, Toxicol. Sci. 54 (2000) 154-167. doi:10.1093/toxsci/54.1.154.

[18] A.M. Soto, H. Justicia, J.W. Wray, C. Sonnenschein, p-Nonyl-phenol: an estrogenic xenobiotic released from" modified" polystyrene., Environ. Health Perspect. 92 (1991) 167.

[19] T. Nishihara, J. Nishikawa, T. Kanayama, F. Dakeyama, K. Saito, M. Imagawa, et al., Estrogenic activities of 517 chemicals by yeast two-hybrid assay, J. Health Sci. 46 (2000) 282-298.

[20] H. Fang, W. Tong, W.S. Branham, C.L. Moland, S.L. Dial, H. Hong, et al., Study of 202 natural, synthetic, and environmental chemicals for binding to the androgen receptor, Chem. Res. Toxicol. 16 (2003) 1338-1358.

[21] E.J. Routledge, J. Parker, J. Odum, J. Ashby, J.P. Sumpter, Some alkyl hydroxy benzoate preservatives (parabens) are estrogenic, Toxicol. Appl. Pharmacol. 153 (1998) 12-19.

[22] K.C. Ahn, B. Zhao, J. Chen, G. Cherednichenko, E. Sanmarti, M.S. Denison, et al., In Vitro Biologic Activities of the Antimicrobials Triclocarban, Its Analogs, and Triclosan in Bioassay Screens: Receptor-Based Bioassay Screens, Environ. Health Perspect. 116 (2008) 1203-1210. doi:10.1289/ehp.11200.

[23] R.H.M.M. Schreurs, J. Legler, E. Artola-Garicano, T.L. Sinnige, P.H. Lanser, W. Seinen, et al., In vitro and in vivo antiestrogenic effects of polycyclic musks in zebrafish, Environ. Sci. Technol. 38 (2004) 997-1002.

[24] D.B.D. Simmons, V.L. Marlatt, V.L. Trudeau, J.P. Sherry, C.D. Metcalfe, Interaction of Galaxolide ${ }^{\circledR}$ with the human and trout estrogen receptor-\$alpha\$, Sci. Total Environ. 408 (2010) 6158-6164.

[25] L. Granier, M. Chevreuil, Behaviour and spatial and temporal variations of polychlorinated biphenyls and lindane in the urban atmosphere of the Paris area, France, Atmos. Environ. 31 (1997) 3787-3802.

[26] F. Alliot, E. Moreau-Guigon, C. Bourges, A. Desportes, M.-J. Teil, M. Blanchard, et al., A multiresidue method for characterization of endocrine disruptors in gaseous and particulate phases of ambient air, Atmos. Environ. 92 (2014) 1-8. doi:10.1016/j.atmosenv.2014.02.044.

[27] A.M. Peck, K.C. Hornbuckle, Synthetic musk fragrances in urban and rural air of lowa and the Great Lakes, Atmos. Environ. 40 (2006) 6101-6111.

[28] A. Maroto, R. Boqué, J. Riu, F.X. Rius, Evaluating uncertainty in routine analysis, TrAC Trends Anal. Chem. 18 (1999) 577-584. doi:10.1016/S0165-9936(99)00151-X.

[29] A. Maroto, J. Riu, R. Boqué, F. Xavier Rius, Estimating uncertainties of analytical results using information from the validation process, Anal. Chim. Acta. 391 (1999) 173-185. doi:10.1016/S0003-2670(99)00111-7.

[30] P. Dehouck, E. Van Looy, E. Haghedooren, K. Deckers, Y. Vander Heyden, E. Adams, et al., Analysis of erythromycin and benzoylperoxide in topical gels by liquid chromatography, J. Chromatogr. B. 794 (2003) 293-302. 
[31] A. Maroto, R. Boqué, J. Riu, F.X. Rius, Measurement uncertainty in analytical methods in which trueness is assessed from recovery assays, Anal. Chim. Acta. 440 (2001) 171-184. doi:10.1016/S0003-2670(01)01058-3.

[32] Y. Liu, L. Zhu, X. Shen, Polycyclic aromatic hydrocarbons (PAHs) in indoor and outdoor air of Hangzhou, China, Environ. Sci. Technol. 35 (2001) 840-844.

[33] J.C. Wallace, I. Basu, R.A. Hites, Sampling and Analysis Artifacts Caused by Elevated Indoor Air Polychlorinated Biphenyl Concentrations, Environ. Sci. Technol. 30 (1996) 2730-2734. doi:10.1021/es950862d.

[34] J.C. Chuang, S.W. Hannan, N.K. Wilson, Field comparison of polyurethane foam and XAD-2 resin for air sampling for polynuclear aromatic hydrocarbons, Environ. Sci. Technol. 21 (1987) 798804. doi:10.1021/es00162a011.

[35] R.A. Rudel, D.E. Camann, J.D. Spengler, L.R. Korn, J.G. Brody, Phthalates, alkylphenols, pesticides, polybrominated diphenyl ethers, and other endocrine-disrupting compounds in indoor air and dust, Environ. Sci. Technol. 37 (2003) 4543-4553.

[36] O. Blanchard, P. Glorennec, F. Mercier, N. Bonvallot, C. Chevrier, O. Ramalho, et al., Semivolatile Organic Compounds in Indoor Air and Settled Dust in 30 French Dwellings, Environ. Sci. Technol. 48 (2014) 3959-3969. doi:10.1021/es405269q.

[37] H. Fromme, T. Lahrz, M. Piloty, H. Gebhart, A. Oddoy, H. Rüden, Occurrence of phthalates and musk fragrances in indoor air and dust from apartments and kindergartens in Berlin (Germany), Indoor Air. 14 (2004) 188-195.

[38] J. Regueiro, C. Garcia-Jares, M. Llompart, J.P. Lamas, R. Cela, Development of a method based on sorbent trapping followed by solid-phase microextraction for the determination of synthetic musks in indoor air, J. Chromatogr. A. 1216 (2009) 2805-2815.

[39] G.G. Ying, B. Williams, R. Kookana, Environmental fate of alkylphenols and alkylphenol ethoxylates-a review, Environ. Int. 28 (2002) 215-226.

[40] R.A. Rudel, R.E. Dodson, L.J. Perovich, R. Morello-Frosch, D.E. Camann, M.M. Zuniga, et al., Semivolatile endocrine-disrupting compounds in paired indoor and outdoor air in two northern California communities, Environ. Sci. Technol. 44 (2010) 6583-6590.

[41] I. Saito, A. Onuki, H. Seto, Indoor air pollution by alkylphenols in Tokyo, Indoor Air. 14 (2004) 325-332.

[42] S.A. Batterman, S. Chernyak, C. Jia, C. Godwin, S. Charles, Concentrations and emissions of polybrominated diphenyl ethers from US houses and garages, Environ. Sci. Technol. 43 (2009) 2693-2700.

[43] Y.Y. Naumova, S.J. Eisenreich, B.J. Turpin, C.P. Weisel, M.T. Morandi, S.D. Colome, et al., Polycyclic Aromatic Hydrocarbons in the Indoor and Outdoor Air of Three Cities in the U.S., Environ. Sci. Technol. 36 (2002) 2552-2559. doi:10.1021/es015727h.

[44] C.S. Li, Y.S. Ro, Indoor characteristics of polycyclic aromatic hydrocarbons in the urban atmosphere of Taipei, Atmos. Environ. 34 (2000) 611-620.

[45] P. Bohlin, K.C. Jones, H. Tovalin, B. Strandberg, Observations on persistent organic pollutants in indoor and outdoor air using passive polyurethane foam samplers, Atmos. Environ. 42 (2008) 7234-7241. doi:10.1016/j.atmosenv.2008.07.012.

[46] P. Bohlin, O. Audy, L. Škrdlíková, P. Kukučka, Š. Vojta, P. Přibylová, et al., Evaluation and guidelines for using polyurethane foam (PUF) passive air samplers in double-dome chambers to assess semi-volatile organic compounds (SVOCs) in non-industrial indoor environments, Environ. Sci. Process. Impacts. 16 (2014) 2617-2626.

[47] S. Harrad, S. Hazrati, C. Ibarra, Concentrations of Polychlorinated Biphenyls in Indoor Air and Polybrominated Diphenyl Ethers in Indoor Air and Dust in Birmingham, United Kingdom: 
Implications for Human Exposure, Environ. Sci. Technol. 40 (2006) 4633-4638. doi:10.1021/es0609147.

[48] X. Zhang, M.L. Diamond, M. Robson, S. Harrad, Sources, emissions, and fate of polybrominated diphenyl ethers and polychlorinated biphenyls indoors in Toronto, Canada, Environ. Sci. Technol. 45 (2011) 3268-3274.

[49] J.G. Allen, M.D. McClean, H.M. Stapleton, J.W. Nelson, T.F. Webster, Personal exposure to polybrominated diphenyl ethers (PBDEs) in residential indoor air, Environ. Sci. Technol. 41 (2007) 4574-4579. 